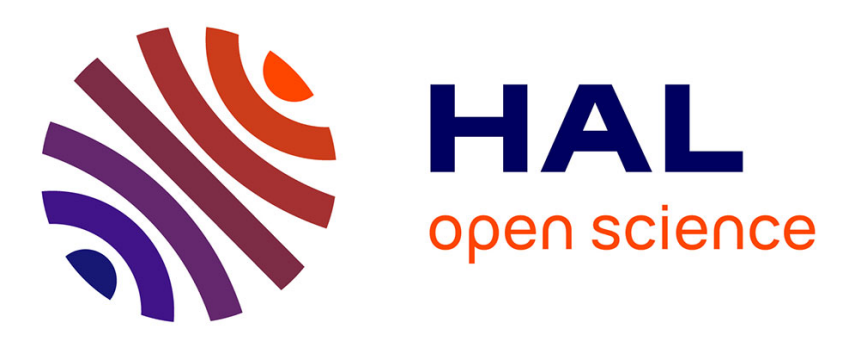

\title{
Do Food Quality Schemes and Net Price Premiums Go Together?
}

Sylvette Monier-Dilhan, Thomas Poméon, Michael Böhm, Ruzica Brečić, Peter Csillag, Michele Donati, Hugo Ferrer-Pérez, Lisa Gauvrit, José M. Gil, Việt Hoàng, et al.

\section{To cite this version:}

Sylvette Monier-Dilhan, Thomas Poméon, Michael Böhm, Ruzica Brečić, Peter Csillag, et al.. Do Food Quality Schemes and Net Price Premiums Go Together?. Journal of Agricultural \& Food Industrial Organization, 2020, 10.1515/jafio-2019-0044 . hal-03102266

\section{HAL Id: hal-03102266 https://hal.inrae.fr/hal-03102266}

Submitted on 21 Jun 2021

HAL is a multi-disciplinary open access archive for the deposit and dissemination of scientific research documents, whether they are published or not. The documents may come from teaching and research institutions in France or abroad, or from public or private research centers.
L'archive ouverte pluridisciplinaire HAL, est destinée au dépôt et à la diffusion de documents scientifiques de niveau recherche, publiés ou non, émanant des établissements d'enseignement et de recherche français ou étrangers, des laboratoires publics ou privés. 


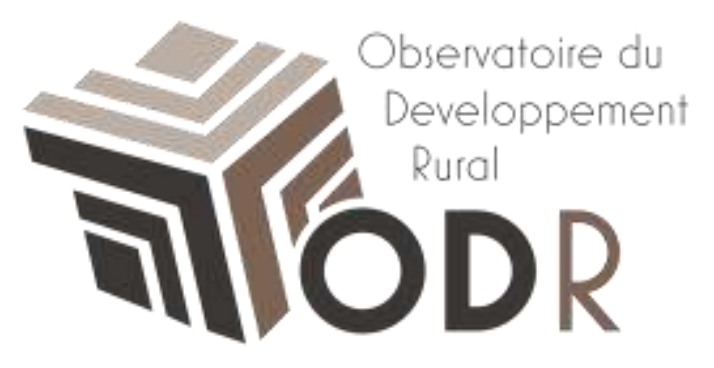

\section{Do food quality schemes and profitability go together?}

Sylvette Monier-Dilhan, Thomas Poméon, Michael Böhm, Ružica Brečić, Péter Csillag, Michele Donati, Hugo Ferrer-López, Lisa Gauvrit, José Maria Gil, Viet Hoang, Apichaya Lilavanichakul, Edward Majewski, Agata Malak-Rawlikowska, Konstadinos Mattas, Orachos Napasintuwong, An Nguyen, Nikolaou Kallirroi, loannis Papadopoulos, Stefano Pascucci, Jack Peerlings, Bojan Ristic, Kamilla Knutsen Steinnes, Žaklina Stojanovic, Marina Tomić, Áron Török, Mario Veneziani, Gunnar Vitters $\varnothing$, Valentin Bellassen.

$N^{\circ}$ 2019-01 Document de travail 


\section{Do food quality schemes and profitability go together?}

Sylvette Monier-Dilhana, Thomas Poméona, Michael Böhm ${ }^{\text {, }}$ Ružica Brečićc, Péter Csillagd, Michele Donatie, Hugo Ferrer-López ${ }^{f}$, Lisa Gauvrit', José Maria Gil ${ }^{f}$, Viet Hoangg, Apichaya Lilavanichakulh, Edward Majewski', Agata Malak-Rawlikowskai, Konstadinos Mattasj, Orachos

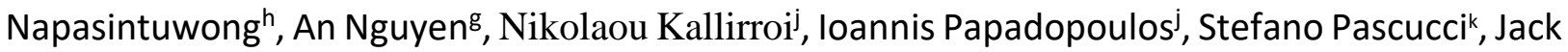
Peerlingsk, , Bojan Ristic', Kamilla Knutsen Steinnes ${ }^{m}$, Žaklina Stojanovic', Marina Tomićc, Áron Török $^{n, d}$, Mario Veneziani ${ }^{e}$, Gunnar Vitters $\emptyset^{m}$, Valentin Bellassen ${ }^{\circ}$

a US ODR, INRA, 31326, Auzeville, France - Corresponding authors

${ }^{b}$ ECOZEPT, Germany

c University of Zagreb, Croatia

d ECO-SENSUS Research and Communication, Hungary

e University of Parma, Italy

${ }^{f}$ Centre for Agro-Food Economy \& Development, Spain

g University of Economics Ho Chi Minh City, Vietnam

h Kasetsart University, Thailand

'Warsaw University of Life Science, Poland

jAristotle University of Thessaloniki, Greece

k Wageningen University, the Netherlands

'University of Belgrade, Serbia

m Consumption Research Norway SIFO, Oslo Metropolitan University, Norway

${ }^{n}$ Corvinus University of Budapest, Hungary

- CESAER, AgroSup Dijon, INRA, Univ. Bourgogne Franche-Comté, 21000 Dijon, France

\section{Abstract}

This article addresses the issue of the profitability of Food Quality Scheme (FQS) products as compared to reference products, which are defined as analogous products without quality label. We approach this question by taking into account the level of the value chain (upstream, processing, and downstream), the sector (vegetal, animal, seafood) and the type of FQS (PGI, PDO, Organic). We collected original data for several products produced in selected European countries, as well as in Thailand and Vietnam. Comparisons depending on value chain level, sector and FQS are possible by using two comparable indicators: price premium and net price premium (including cost differential). The following principal conclusions were reached: 1) Price is higher for FQS products than for the reference products, regardless of the production level, the type of FQS or the sector; 2) Price premiums generated by FQS do not differ along the value chain, nor between sectors (vegetal, animal or seafood/fish); 3) Price premium for organic products is significantly higher than for PGI products, and this conclusion holds at upstream and processing levels, taking into account the costs directly related to production; 4) All organic products and almost all PDO and PGI products analysed benefit from a positive quality rent; 5) At upstream level and processing level, the relative weight of intermediate consumption in the cost structure is lower for organic products than for reference products.

Keywords: Food Quality Scheme, geographical indication, organic, price premium, profitability JEL: Q01, Q18, C12 


\section{Introduction}

The EU promotes four principal food quality schemes - Protected Designation of Origin (PDO), Protected Geographical Indication (PGI), Traditional Speciality Guaranteed (TSG) and organic farming - which provide information on credence attributes (geographical origin of food production, production based on a tradition or specific method of production). The use of credible labels enables firms to signal the presence of specific attributes, and thereby to reduce asymmetrical information and create the potential for premiums based on this indication (McCluskey, 2000; Caswell and Anders, 2011; Marette, 2016; Bonanno et al., 2018). The geographical indication (GI) labels, PDOs and PGIs, as part of the Common Agricultural Policy, aim to collectively protect agricultural and food products with a strong link to their geographical origin. Such protection is justified as it enables "consumers to trust and distinguish quality products while also helping producers to market their products better"1. The same factors apply to the organic label, considered by the European Union as both a «specific market responding to consumer demand for organic products » and a way to "promote sustainable agricultural production » (Regulation (EU) 2018/848). TSG refers to a product with specific characteristics in terms of composition, mode of production or processing, based on tradition (Council Regulation (EC) No. 1151/20012. It is also justified on the basis that it constitutes a tool to promote rural development and improve the income of farmers, as well as a guarantee to regulate the market and protect consumers.

Food quality schemes (FQS) have a considerable economic impact, especially in regions producing many traditional foods, and/or in less-favoured areas (Parrot et al., 2002; Rudow, 2014). They concern various categories of product: wine, cheese, beer, vegetables, fruit, fresh and processed meat, spices, etc. In this article, we focus on food, leaving aside the specificities of the wines, beverages and spirits sector ${ }^{2}$. We also exclude TSG as they are less widespread in terms of countries and categories of products. FQS are intended to provide high quality products and a more sustainable supply chain, including fair and viable economic return for economic actors. Our focus here is to analyse the extent to which FQS meet their objectives of increasing added value and ensuring its fair distribution among producers, processors and retailers, compared to conventional value chains.

The purpose of this paper is thus to contribute to increased generic and empirical knowledge of the economic impacts of FQS. Accordingly, it is necessary to draw on a large number of cases studies which use a common framework. Based on a research project involving twelve European and two extra-European partners to collect data on 27 case studies (PDO, PGI and organic), using the same method and quality control procedure (Bellassen et al. 2016 and 2017), we assess the sustainability of FQS in all its components. Economic sustainability is analysed here, by calculating price premium and taking into account the main production costs at different levels of

\footnotetext{
1 https://ec.europa.eu/info/food-farming-fisheries/food-safety-and-quality/certification/quality-labels/qualityschemes-explained\#aims

${ }^{2}$ In relation to the wines and spirits sector, the importance of PDO and PGI labels is crucial, and strategies on FQS and its impacts are not comparable with the food sector.
} 
the value chain through the net price premium. For each case, we compare economic indicators with those of a reference product (analogous product obtained with conventional production process). We are thus able to investigate different determinants of FQS economic performance, mainly in relation to level (farm, processing and retail), production sectors (vegetal and animal; processed or raw productions) and type of FQS (PDO, PGI and organic). We aim to answer the following questions: whether FQS products allow for quality rent, which FQS, which production sectors and at which value chain levels.

In addition to the study's contribution to a multi-sectorial and multi-country approach, the originality of our work stems from including PDO, PGI and organic value chains in the same study. This not only enables a comparison to make between the economic performance of FQS and that of reference products, but also allows us to gain insight into the differential impact of these three main types of FQS.

The paper is structured as follows: Section 2 presents a brief overview of previous insights into the economic performance of FQS; Section 3 sets out the data collection process and methodology; Section 4 presents the results and comments on the main findings; and our conclusions are set out in section 5 .

\section{Expansion and global economic impacts of the main FQS in Europe}

The extent of FQS expansion differs according to sectors and countries. Figures on volumes and values for GI and organic sector products are available with varying degrees of regularity and precision, depending on countries and periods. Several studies and publications help to illustrate FQS sector economic extent, especially in relation to the main sectors and countries concerned.

Focusing only on the food sector, Geographical indications (GI) have recently experienced significant growth, with more than 720 PDO and 870 PGI registered in the EU DOOR database as of July 2019, compared to 546 and 519 respectively in 2012. They mainly relate to Community production but there are also some extra-Community entries, with 50 PDO/PGI registered from non-members countries. Organic farming has also been expanding at a rapid rate, with more than 295000 organic farmers and 12 million ha of organic land area at the end of 2016 (compared to 250000 and 10 million ha in 2012).

In term of numbers of registered PDO/PGI, three countries (Italy, France and Spain) accounted for more than half of EU registered food GI. Figures on sales show that the number of registered GI does not directly reflect its significance: Germany has few GI but is the third country in the EU in terms of sales value of food GI products (AND, 2012). FQS economic impact is generally greater in relation to turnover than to volume. This difference between volume and value share indicates significantly higher average prices for GI cheese. The relative importance of GI to national food and drink industry turnover differs across EU countries, from approximately $0 \%$ to $15 \%$. In relation to the EU food sector alone, 764 GI created a value of 14.5 billion $€$ in 2008 (at wholesale level; estimated at 21 billion at retail level), representing $2.5 \%$ of total food consumption (European Commission, 2010). According to the AND-International study (2012) 
on GI production values, global turnover at wholesale level represented 15.8 billion $€$ in 2010 . The main sectors were cheeses (39\%), meat products (20\%) and beers (15\%). In 2008, PDO and PGI represented $9 \%$ of the European Union cheese production of the member states (corresponding to approximately 3 to $4 \%$ of world cheese production) and more than $15 \%$ of the total value of EU cheese production (European Commission, 2010). At the national level the GI share amounts to more than 50\% of Italian cheese production (ISMEA Qualivita, 2018), and accounted for $14 \%$ of the French cheese market in terms of volume (CNAOL-INAO, 2019).

Expansion in organic farming also differs among countries and sectors. In 2016, the EU organic market accounted for 30.7 billion $€$, representing 47.7\% more than in 2012 (Agence Bio, 2017). France and Germany together represent $29 \%$ of the EU population but half of EU annual organic consumption. Organic area has also grown rapidly and in 2016 represented $6.2 \%$ of the European agricultural area with 12 million hectares, compared to 9.7 million in 2012. The share of organic farms and area by country vary significantly, from 0.2 in Malta to $22 \%$ in Austria (Agence Bio, 2017). Organic geography does not completely correspond to GI geography: although countries are more dynamic in relation to both types of FQS (Italy and Spain), some countries have a stronger GI but weaker organic sector (France) or vice versa (e.g. Austria).This situation reflects different patterns of food cultures and policies, resulting in the development of greater or lesser interest in various food quality issues (food heritage, environment, health, etc.). FQS thus have significant and increasing weight in the European food sector, depending on the type of FQS, sector and country.

One issue is to understand the attractiveness of FQS from both a supply and demand point of view, especially in light of its economic impacts. Consumers' willingness to pay (WTP) demonstrates interest for specific quality attributes (origin and method of production). This WTP pays out to the various actors, generating a price premium which compensates possible extra costs and/or improving gross margins. Collective organisation linked with FQS may also enable value chain actors to better control the added value generated and its distribution. Several studies (Vandecandelaere et al., 2018; Cei et al., 2018; Belletti et al., 2017; Sanders et al., 2016; Crowder and Reganold, 2015; Areté, 2013; Bontemps et al., 2013; London School of Economics, 2008) point out other direct and indirect economic impacts that FQS may have, especially by influencing the structure and organisation of supply chains: visibility, stability, market access, reputation, access to institutional support, etc.

Many articles have studied the effects of label information on WTP for food attributes. McCluskey and Loureiro (2003) led empirical research on WTP for several types of food quality or attribute labelling (eco-labels, genetically modified free food labels, U.S. state agricultural-product labels and European PGI labels, BSE-tested-beef labels and "Fair Trade" labels). They find that consumers must perceive high quality in order for the food product to command a premium, particularly for socially responsible and origin-based products. Several studies mobilized purchasing records and surveys to determine consumers' WTP for PDO/PGI. Most of them dealt with a single product: Fotopoulos and Krystallis (2003) analysed the PDO Zagora apples in the Greek market; Ahrendsen and Majewski (2017) focused on the Protected Geographical Indication Recognition and the WTP for Grojec Apple; Garavaglia and Mariani (2017) analysed the case of 
PDO Dry-Cured Ham in Italy. In relation to organic products, Dimitri and Dettmann (2012) studied consumers' behaviour regarding three product categories (vegetable, fruit and milk). Maigné et al. (2017) adopted a comprehensive approach by focusing on the budget share which a consumer devotes to organic products. Deselnicu et al. (2013) conducted a meta-analysis of studies estimating price premium for differentiated agricultural products. They show that differences across product characteristics (food categories) and institutions with stricter or less strict regulations (PDO, PGI, trademarks) explain a large proportion of the variance in estimated premiums.

Several studies also stress FQS indirect impacts on price premium through stronger collective organization (Barjolle and Jeanneaux 2012; Areté, 2013; Vandecandelaere et al., 2018). FQS may increase the possibility of controlling supply and/or reaching price agreements among different actors in the value chain. GI protects intellectual property rights for recognised designation, preserving the local supply chain from competition. FQS improves visibility and recognition for a product and may help to access a new domestic or import market. It could also result in better access to promotion funds, investment aid and support under rural development policy (at the local, national or European level). Finally, because it relies on collective organisation and territory promotion, GIs have positive indirect impact on the area as a whole. Although organic production is not directly connected to an area, local impacts are similar as strong local organic development is linked to collective organisation and involvement (Allaire et al., 2015).

Both consumers' WTP and supply chain regulations explain the higher relative prices of FQS products. Several studies highlighted significant price premium and value added for a range of FQS in Europe, based on data comparing FQS price (organic or GI) to a conventional reference (AND, 2012; Areté, 2013; Sanders et al., 2016; Vandecandelaere et al., 2018). Through a case study-based approach, focusing on one type of FQS, they showed that almost all GI or organic products had a price premium compared to the standard product. However, they pointed to significant variability among GIs, and failed to draw generic conclusions on determinants (Cei et al., 2018). Some studies have aimed to look beyond price premium by calculating gross margins and evaluating factors enabling added value for GI (Areté, 2013). Conclusions tend towards a positive profitability differential for GI, but the results are not entirely clear. The small number of case studies and the significant variability limit the scope of the analysis. We know little about the costs and benefits balance of FQS and whether or not price premium simply compensates extra costs deriving from the binding requirements for FQS production. Regarding organic label, Crowder and Reganold (2015) conducted a meta-analysis comparing financial performance of organic and conventional agriculture. They showed that organic agriculture is significantly more profitable. However, there is few insights about organic profitability considering the whole value chain, to measure the way the premium is shared. Finally, there is few or no evidence to enable results to be compared across different levels, sectors as well as types of FQS. 


\section{Data and methods}

\subsection{Data on FQS and reference products}

This paper draws on a database of the 27 case studies into which data is entered by researchers in each country (see Appendix 1). Bellassen et al. (2016) describe data collection guidelines. Besides the criteria of availability of data, the reference product for each FQS product is chosen which most closely resembles the studied product, in terms of location (same context and scale) and type of product (varieties, production systems, etc.). Nevertheless choosing an equivalent reference product for comparison is not always an easy task. For a GI or organically produced FQS product, the ideal reference would be a standard product of the same variety. Yet, data may be scarce at this degree of detail (variety and area), or it may even be the case that all the variety production is under FQS. The reference would then be another main variety or a mixture of other main varieties, based on figures on a regional or national scale. For PDO Comté cheese, the reference product is Emmental PGI cheese produced in a larger central eastern French area. For PDO Zagora apple, the equivalent reference product would ideally be standard apple produced in the same area. Nevertheless, as almost all the apple production in the area is under GI, apple production from another comparable region has been used as a reference. In the case of PDO Kalocsai paprika powder, nearly all paprika production used for powder at a national scale is for PDO production. Non-PDOP paprika powder is produced with imported (mainly Chinese) paprika. The list of reference products and main data sources are presented in a comprehensive way in the article by Bellassen \& al. Some reference products differ from this article as the result of an opportunity to obtain economic data for a product closer to the FQS product (see Appendix 2).

\subsection{Indicators}

The economic indicators selected for this study are price premium and net price premium. As a first step, we analyse the standard price premium, according to which the price is the amount received by the economic agent for each product unit at a given level of the value chain (upstream, processing and retail).

Taking the price of the reference product as benchmark, the price premium (PP) is usually defined as follows:

(1) $P P=\frac{P^{*}-P^{r}}{P^{r}}$

With: $\mathrm{P}=$ price; * refers to $\mathrm{FQS}$ and $r$ to reference product.

This ratio, expressed as a percentage of the reference product price, allows direct comparisons between products and between the three levels of the supply chain for the same product.

To evaluate the profitability of the FQS production at upstream level and processing level, we take into account costs and subsidies involved to produce (farm) or collect (fisheries) raw material and to process it. We were unable to address issues of profitability at retail level. Data on costs were unavailable, as retailers are reluctant to communicate these key figures. Profitability level for retailers depends on marketing channels (supermarkets, exports, short supply chains, etc.), that may differ greatly between FQS and the corresponding reference, and within FQS examples 
themselves. Determinants are related to volumes, perishability and other logistical aspects, which are not easy to link directly to the FQS or non-FQS value chain.

In order to evaluate the most relevant costs for the study of FQS profitability ${ }^{3}$, we isolate the effects of some key items of expenditure:

- Intermediate consumption (IC): FQS specifications generally imply higher costs due to some inputs use restrictions (especially for organic) and/or more specific and expensive inputs (feed from the area, organic fertilizers, etc.);

- Wages (W): an indicator of either the level of employment qualification or the volume of employment;

- Subsidies (S), at upstream level, are considered as negative costs: making it possible to evaluate the extent to which the economic pillar of the sustainability of FQS products is linked to subsidies.

In order to measure and compare the actual profitability of FQS, we have chosen to analyse the net price premium (NPP), taking into account the production costs necessary to produce under FQS $^{4}$. The analysis of NPP is more straightforward than usual profitability indicators (gross margin, etc.) and directly connected to PP analysis. Both PP and NPP are expressed as a percentage of the price of the reference product. PP takes into account the buyer's willingness to pay for quality, and NPP accounts for the quality rent that finally benefits economic actors. NPP directly reflects the gain obtained by the farmer or the processor for producing in a FQS value chain.

In order to calculate the NPP, we first calculate the price of the FQS product ( $\mathrm{P}^{*}$ ') equal to that of the reference product $\left(\mathrm{P}^{\mathrm{r}}\right)$ plus the incremental average cost differential between the two products. $P^{* \prime}$ is the price corresponding to the difference in costs between the FQS product and the standard product. That is:

$$
\mathrm{P}^{*},=\mathrm{P}^{\mathrm{r}}+\left(\mathrm{C}^{*} / \mathrm{Q}^{*}-\mathrm{C}^{\mathrm{r}} / \mathrm{Q}^{\mathrm{r}}\right),
$$

with: $\mathrm{P}=$ price; $\mathrm{Q}=$ quantity; $\mathrm{C}=$ costs; * refers to $\mathrm{FQS}$ and $\mathrm{r}$ to reference:

$$
C^{i}=\sum_{j} C_{j}^{i}
$$

where: $\mathrm{i}$ refers to $*$ or $\mathrm{r}$, and $\mathrm{j}$ is the index for the different costs or incomes involved in the production.

Costs are expressed as a percentage (c) of the turnover, $C_{j}=c_{j} P Q$, so that $\mathrm{P}^{*}$ ' can be expressed as:

\footnotetext{
${ }^{3}$ Additional methodological details are available in Bellassen et al., 2016.

${ }^{4}$ In Bellassen et al. (2016 and 2017), analysis is done using the price premium, the gross operating margin and the net results. These indicators involve the same cost items: Gross value added $=$ Turnover $-\mathrm{IC}+\mathrm{S}$ and Gross operating margin $=$ Turnover $-\mathrm{IC}+\mathrm{S}-\mathrm{W}$.
} 


$$
\text { (2) } P^{* \prime}=P^{r}+\sum_{j}\left(c_{j}^{*} P^{*}-c_{j}^{r} P^{r}\right)
$$

To compare net price premium along the value chain, we express it as a percentage of reference product price.

$$
\text { (3) } \mathrm{NPP}=\frac{P^{*}-P^{* \prime}}{P^{r}}
$$

A positive sign of equation (3) indicates that the FQS product allows for a quality rent, i.e. FQS improves profitability for the producer compared to the reference. By replacing $P^{* \prime}$ following the expression (2), we obtain:

$$
N P P=\frac{P^{*}-P^{r}-\sum_{j}\left(\mathrm{c}_{j}^{*} P^{*}-\mathrm{c}_{j}^{r} P^{r}\right)}{P^{r}}
$$

It should be noted that the numerator is the difference between the net price of the FQS product $\left(\mathrm{P}^{*}-\mathrm{C}^{*} / \mathrm{Q}^{*}\right)$ and the net price of the standard product $\left(\mathrm{P}^{\mathrm{r}}-\mathrm{C}^{\mathrm{r}} / \mathrm{Q}^{\mathrm{r}}\right)$.

$$
\text { (4) } N P P=P P-\frac{\sum_{j}\left(\mathrm{c}_{j}^{*} P^{*}-\mathrm{c}_{j}^{r} P^{r}\right)}{P^{r}}
$$

The net price premium is then obtained from the usual price premium by subtracting (adding for subsidies) the cost differentials, expressed as a percentage of the price of the standard product. The difference between NPP and PP provides direct information on the possible extra costs to produce the FQS product compared to the reference product, and finally on the actual profitability differential linked to FQS.

\subsection{Tests}

We performed non-parametric tests to determine whether there are statistically significant differences between profitability of FQS with respect to reference products in terms of price premiums and net price premiums. The analysis was conducted based on the level of the value chain, the sector and the type of FQS. Non-parametric tests do not assume that data derive from a distribution that can be completely described by two parameters (mean and standard deviation), in the way that normal distribution can. Such tests are suitable for small sets of observation. We perform Kruskal-Wallis or Mann-Whitney tests to determine whether there are statistically significant differences between groups of FQS price premiums and we use the median test to arbitrate whether medians are equal. In order to study the possible differences between price premiums of FQS products and reference products and between the cost structures of FQS products and reference products we implement Wilcoxon signed-rank tests.

\section{Results}

\subsection{Price premium}

The following box plot (Figure 1) shows the price premium distribution (69 observations). 


\section{Figure 1. Distribution of price premium for FQS (all levels, sectors and type of FQS included)}

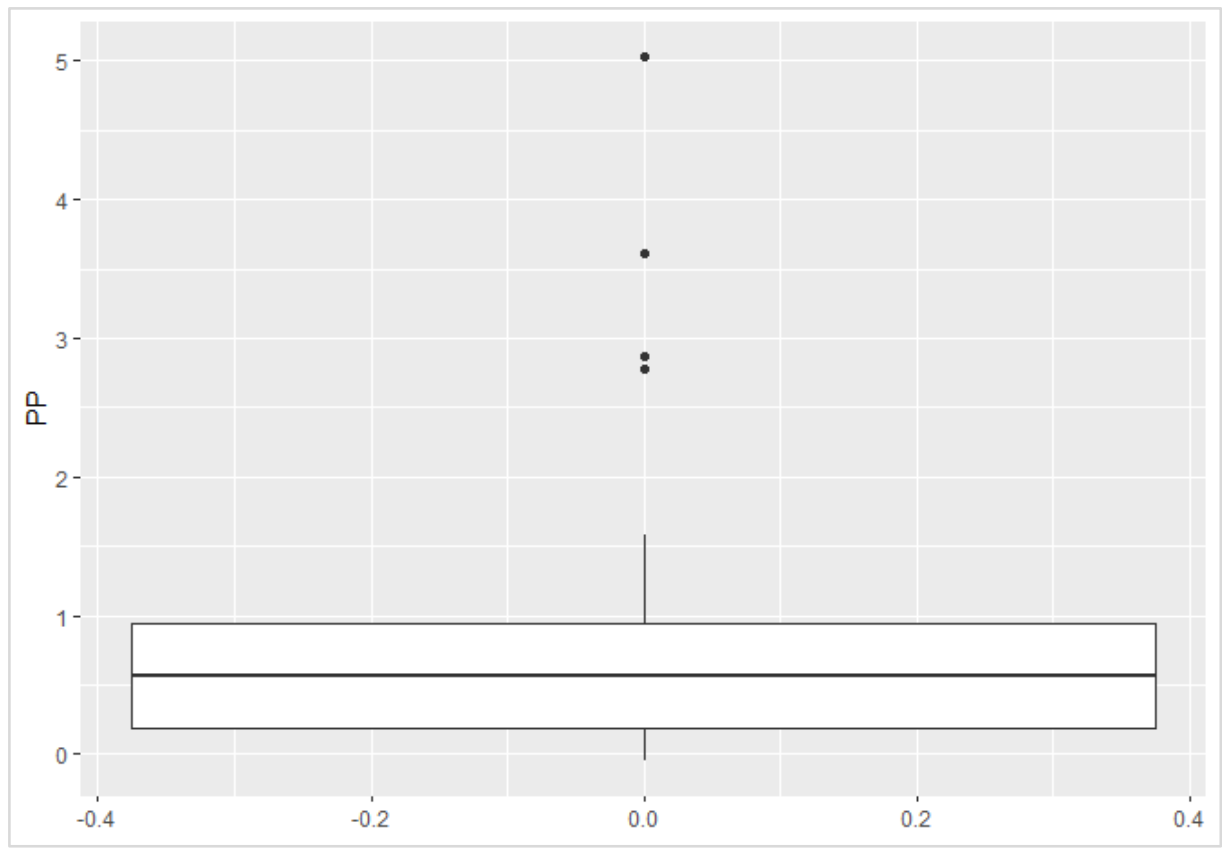

The Wilcoxon signed-rank test concludes, with a very high degree of significance, that the median of PP is positive. Price premium (PP) is positive, or very slightly negative ${ }^{5}$. Four PPs stand out as outliers:

- $277 \%$ for Polish Organic pasta at processing level;

- $287 \%$ for PGI Lofoten Stockfish, at processing level;

- $361 \%$ for PDO Opperdoezer Ronde potato at upstream level;

- and $502 \%$ for Polish Organic pasta at upstream level.

These PP outlier cases are FQS products characterized by small production volumes and very specific niche markets; and their references are commodity products, with low prices due to high volumes of production and low levels of differentiation (potatoes, salt fish and pasta). These factors tend to increase the observed gap between FQS and reference values. Our analysis has been conducted on the whole sample, including outlier values. The sample is already relatively small, and outliers do not represent mistakes due to errors in observation, measurement or calculation, rather they correspond to specific and real situations. Moreover we have verified that the conclusions presented below are valid in relation to both the total sample (69 observations) and the sample without the "outliers" (65 observations).

In order to analyse the variability of price premium, we have examined variation of price premium based on several factors. Products are considered at different levels of the value chain and differ

\footnotetext{
$5-4.7 \%$ for Dalmatian prusut and $-1.2 \%$ for Lofoten Stockfish both at upstream level. In these cases, differences between FQS and reference products do not relate to actual difference, but to no significant divergence between sources. In relation to Lofoten Stockfish, there is no difference at the fisheries level (fish is the same, whether it is processed in PGI or not); the difference is simply due to the fact that the reference is the national average price for cod fish.
} 
by the sector (animal, vegetal or seafood) and type of FQS (organic, PGI, PDO). Figure 2 illustrates the distribution of price premium according to each category.

Figure 2. Price premium generated by FQS according to product categories

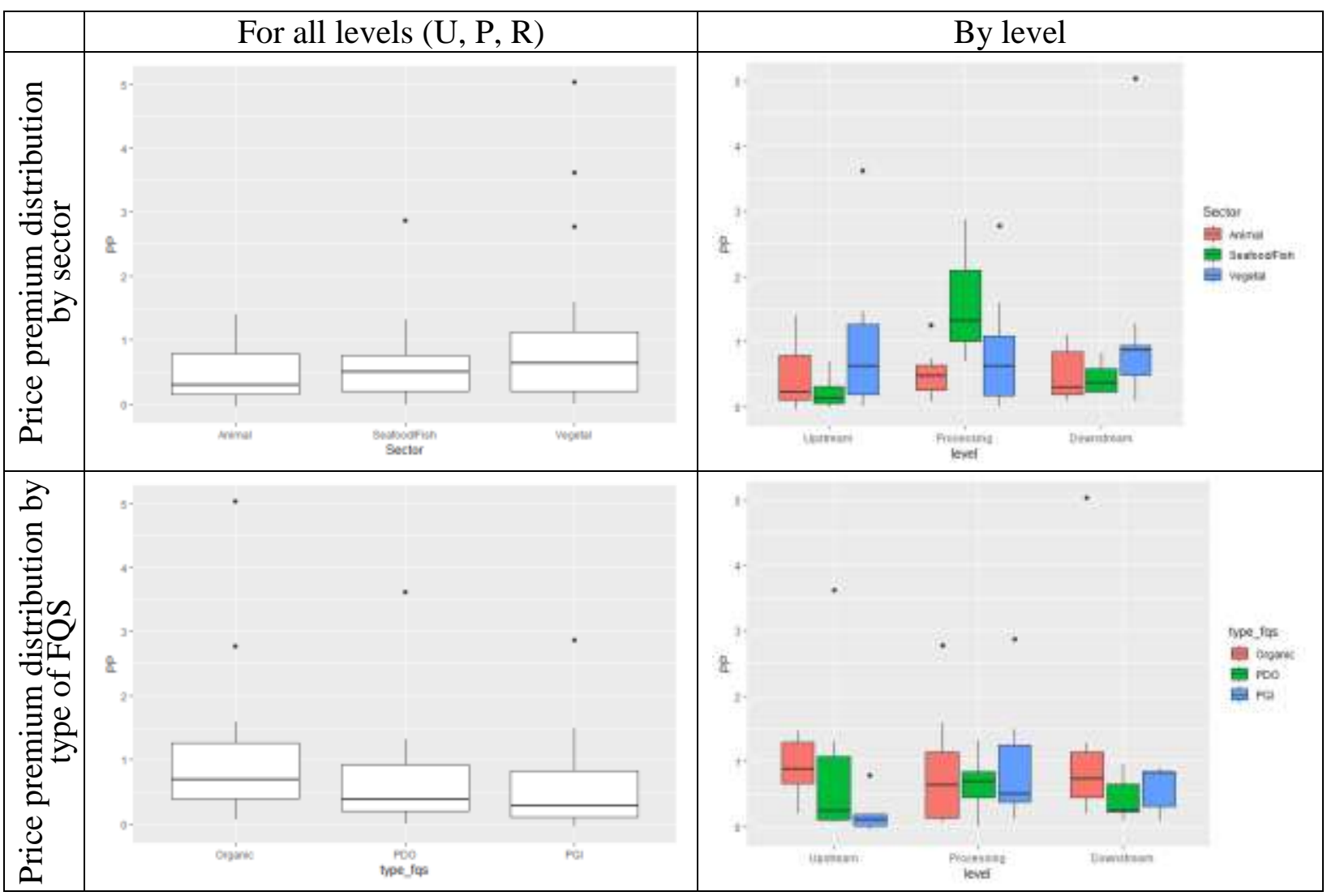

Regardless of the production level, the type of FQS and the sector (animal, vegetal or seafood), price is higher for FQS than for the reference product. The dispersion of PP remains high even within each category. Nevertheless, the lowest PP dispersion is observed among organic products, whereas within GI it is very high, especially for PGI.

Table 1 displays PP medians according to the three reading keys and results of the Kruskal-Wallis tests performed for each classification. 
Table 1. Price premium generated by FQS: Kruskal-Wallis equality-of-populations rank test according to product categories

\begin{tabular}{|c|c|c|c|c|}
\hline \multicolumn{2}{|c|}{ Price Premium } & $\begin{array}{l}\text { \# } \\
\text { observations }\end{array}$ & Median & $\begin{array}{l}\text { Same } \\
\text { population } \\
\text { (P value of } \\
\mathrm{KW} \text { test) }\end{array}$ \\
\hline \multicolumn{2}{|l|}{ Total } & 69 & $56.2 \%$ & \\
\hline \multirow{3}{*}{$\begin{array}{l}\text { By supply } \\
\text { chain } \\
\text { level }\end{array}$} & Upstream & 25 & $20.5 \%$ & \multirow{3}{*}{$\begin{array}{c}\text { Yes } \\
(0.41)\end{array}$} \\
\hline & Processing & 23 & $61.1 \%$ & \\
\hline & Downstream & 21 & $56.5 \%$ & \\
\hline \multirow[t]{3}{*}{ By sector } & Vegetal & 35 & $63.6 \%$ & \multirow{3}{*}{$\begin{array}{c}\text { Yes } \\
(0.32)\end{array}$} \\
\hline & Animal & 23 & $29.4 \%$ & \\
\hline & Seafood & 11 & $50.0 \%$ & \\
\hline \multirow[t]{3}{*}{ By FQS } & PGI & 24 & $29.0 \%$ & \multirow{3}{*}{$\begin{array}{c}\text { No } \\
(0.06)\end{array}$} \\
\hline & PDO & 22 & $37.7 \%$ & \\
\hline & Organic & 23 & $68.7 \%$ & \\
\hline
\end{tabular}

The findings showing a positive price premium are consistent with the results of numerous studies conducted at retail level which exhibit a consumer's willingness to pay (WTP) for organic food (Dimitri and Dettman, 2012; Maigné et al., 2017; Wier et al., 2008), PDO products (Fotopoulos and Krystallis, 2003; Garavaglia and Mariani, 2017; Panin et al., 2015) and PGI products (Ahrendsen and Majewski, 2017). This study demonstrates that this WTP is carried through all the supply chain, with significant PP at upstream and processing level, regardless of product categories.

According to Kruskal-Wallis rank tests (p-value), we conclude that there is no significant difference in terms of PP generated by FQS along the value chain, nor between sectors (vegetal, animal or seafood/fish). However, consideration of the type of FQS does not enable us to conclude that the three samples are from the same population. To go further, we compare samples in pairs by conducting Kruskal-Wallis tests to arbitrate whether pairs of PPs are from the same population and Wilcoxon rank-sum tests to verify whether the medians are equal by pair of FQS type (Table 2). The last classification considers GI (PGI and PDO) versus organic products.

Table 2. Comparison between PP generated by paired type of FQS

\begin{tabular}{|c|c|c|c|c|}
\hline \multicolumn{2}{|l|}{ FQS } & \# Obs & $\begin{array}{l}\text { Same population } \\
\text { (P value) }\end{array}$ & $\begin{array}{l}\text { Same median } \\
\text { (P value) }\end{array}$ \\
\hline \multirow[t]{2}{*}{ PGI \& PDO } & PGI & 24 & \multirow{2}{*}{$\begin{array}{l}\text { Yes } \\
(0.38)\end{array}$} & \multirow{2}{*}{$\begin{array}{l}\text { Yes } \\
(1.0) \\
\end{array}$} \\
\hline & PDO & 22 & & \\
\hline \multirow[t]{2}{*}{ PGI \& Organic } & PGI & 24 & \multirow{2}{*}{$\begin{array}{l}\text { No } \\
(0.02)\end{array}$} & \multirow{2}{*}{$\begin{array}{l}\text { No } \\
(0.03)\end{array}$} \\
\hline & Organic & 23 & & \\
\hline \multirow[t]{2}{*}{ PDO \& Organic } & PDO & 22 & \multirow{2}{*}{$\begin{array}{ll}\text { Difficult } & \text { to } \\
\text { conclude } & \\
(0.12) & \end{array}$} & \multirow{2}{*}{$\begin{array}{l}\text { Yes } \\
(0.3)\end{array}$} \\
\hline & Organic & 23 & & \\
\hline \multirow[t]{2}{*}{ (PGI+PDO) \& Organic } & PGI+PDO & 46 & \multirow{2}{*}{$\begin{array}{l}\text { No } \\
(0.03)\end{array}$} & \multirow{2}{*}{$\begin{array}{l}\text { No } \\
(0.06)\end{array}$} \\
\hline & Organic & 23 & & \\
\hline
\end{tabular}


On the basis of the results of these tests, we conclude that PP for organic products is significantly higher than for PDO and PGI products. This suggests that food quality schemes differ in terms of the capacity of quality differentiation to meet consumer expectations. Another interesting and intuitive result is that PGI products have a significantly lower price premium than PDO ( $p$ value $=0.23)$ and organic products $(p$-value $=0.32)$ at farm level, whereas at processing level there is no difference between PGI and PDO ( $p$-value $=0.13$ ) but this difference remains between GI and organic products ( $\mathrm{p}$-value $=0.55$ ). Indeed, the general principle of PGIs is that raw materials are not specific and that it is the processing level which bears the production constraints and brings specificity to the product.

The question we have to deal with at this stage is: Does the PP cover an additional cost and / or does it correspond (at least to some extent) to an actual quality rent for the producer? The extensive data collection work enables us to answer this question at both upstream level and processing level, through the calculation of the net price premium.

\subsection{Net Price premium}

We conduct the analysis, as a first step, according to production sectors and types of FQS, at both upstream and processing levels and by production levels (Figure 3).

Figure 3. Net Price premium generated by FQS according to product categories

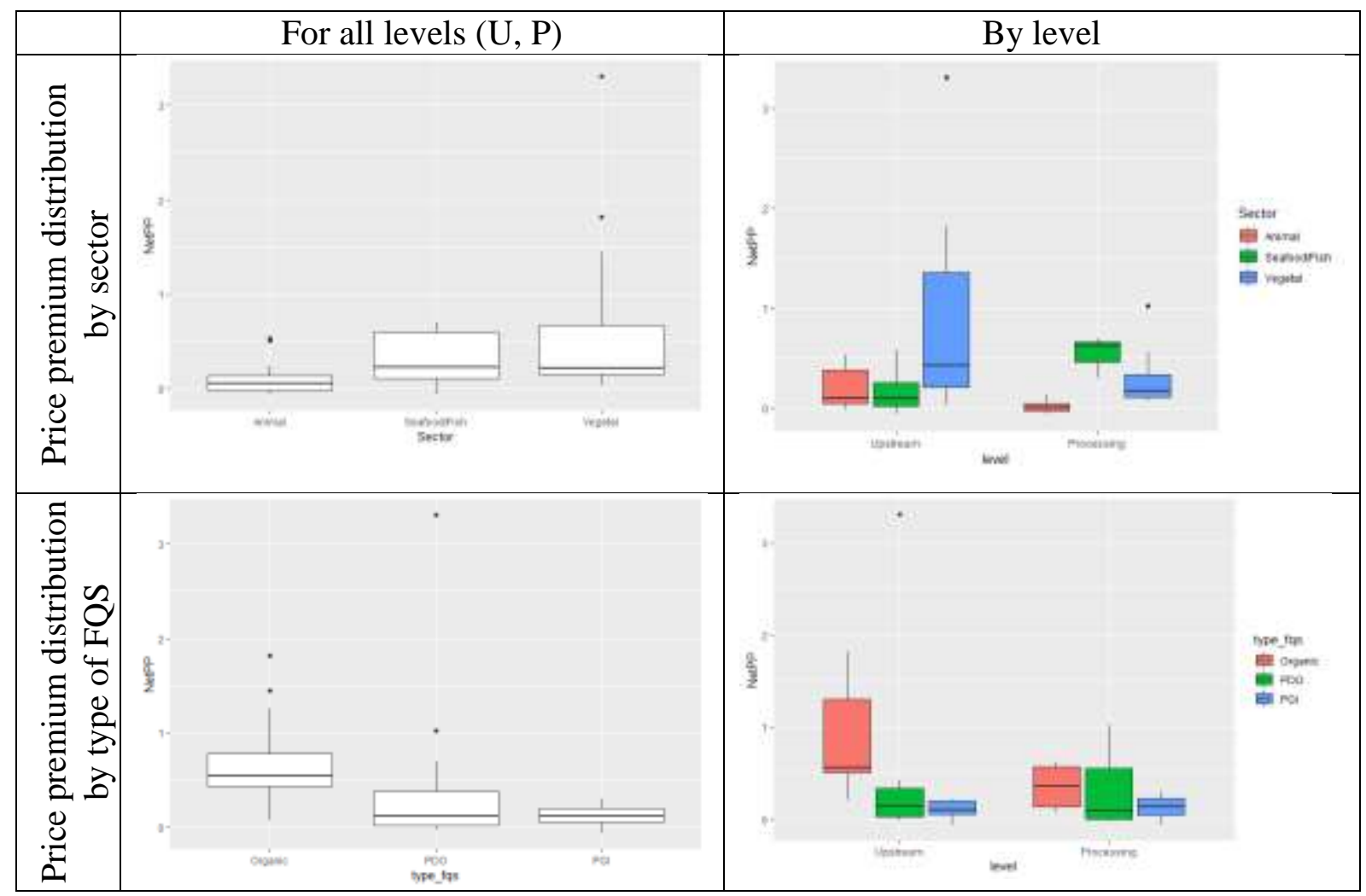

The net price premium (NPP) is lower than the price premium showing that costs to produce FQS products are on average higher than costs to produce standard goods. It must be stressed that variability is much greater for net price premium than for price premium. In relation to price premium, the Wilcoxon signed-rank test concludes, also with a very high degree of significance, that the median of net price premium is positive. 
As shown in Figure 3, NPP is negative in a few case studies. A negative NPP value means that the actual price of the FQS product is too low to cover the costs required to produce the labelled product (see equation 3). This occurs in relation to animal or seafood products, due to mandatory requirements significantly increasing costs. Nevertheless, most FQS products benefit from a quality rent, i.e. a premium that goes beyond additional costs.

We conducted Kruskal-Wallis tests according to supply chain level and type of FQS (Table 3), excluding analysis by sector. This is due to the fact that 8 of the 12 organic products are vegetable products. The vegetal category is thus biased by organic overrepresentation.

Table 3. Net Price premium generated FQS: Kruskal-Wallis equality-of-populations rank test according to product categories

\begin{tabular}{|c|c|c|c|c|}
\hline \multicolumn{2}{|c|}{ Net Price Premium } & $\begin{array}{l}\text { \# } \\
\text { observations }\end{array}$ & Median & $\begin{array}{l}\text { Same } \\
\text { population } \\
\text { ( } P \text { value of } \\
\mathrm{KW} \text { test) }\end{array}$ \\
\hline \multicolumn{2}{|l|}{ Total } & 39 & $17.7 \%$ & \\
\hline \multirow{2}{*}{$\begin{array}{l}\text { By supply } \\
\text { chain } \\
\text { level }\end{array}$} & Upstream & 22 & $21.0 \%$ & \multirow{2}{*}{$\begin{array}{c}\text { Yes } \\
(0.26)\end{array}$} \\
\hline & Processing & 17 & $13.2 \%$ & \\
\hline \multirow[t]{3}{*}{ By sector } & Vegetal & 19 & $21.1 \%$ & \\
\hline & Animal & 13 & $5.3 \%$ & \\
\hline & Sea food & 7 & $29.7 \%$ & \\
\hline \multirow[t]{3}{*}{ By FQS } & PGI & 14 & $11.3 \%$ & \multirow{3}{*}{$\begin{array}{c}\text { No } \\
(0.01)\end{array}$} \\
\hline & PDO & 13 & $11.2 \%$ & \\
\hline & Organic & 12 & $54.2 \%$ & \\
\hline
\end{tabular}

As previously, we conclude that there is no difference in term of net price premium generated along the value chain. Consideration of the type of FQS does make it possible to conclude that the three samples are from the same population. We therefore compare the net price premium of PDO versus PGI, PDO versus organic, PGI versus organic and GI (PGI + PDO) versus organic (Table 4).

Table 4 Comparison between Net PP generated by paired type of FQS using Kruskal-Wallis and Wilcoxon rank-sum tests

\begin{tabular}{|c|c|c|c|c|}
\hline \multicolumn{2}{|l|}{ FQS } & \multirow{2}{*}{$\begin{array}{r}\text { Obs } \\
14 \\
\end{array}$} & \multirow{3}{*}{$\begin{array}{l}\text { Same population } \\
\text { (P value) } \\
\text { Yes } \\
(0.70)\end{array}$} & \multirow{3}{*}{ 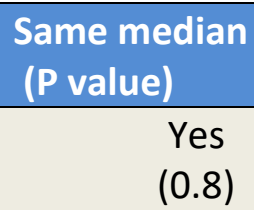 } \\
\hline \multirow[t]{2}{*}{ PGI \& PDO } & PGI & & & \\
\hline & PDO & 13 & & \\
\hline \multirow[t]{2}{*}{ PGI \& Organic } & PGI & 14 & \multirow{2}{*}{$\begin{array}{c}\text { No } \\
(0.001)\end{array}$} & \multirow{2}{*}{$\begin{array}{c}\text { No } \\
(0.02)\end{array}$} \\
\hline & Organic & 12 & & \\
\hline \multirow[t]{2}{*}{ PDO \& Organic } & PDO & 13 & \multirow{2}{*}{$\begin{array}{c}\text { No } \\
(0.03)\end{array}$} & \multirow{2}{*}{$\begin{array}{c}\text { No } \\
(0.01)\end{array}$} \\
\hline & Organic & 12 & & \\
\hline \multirow[t]{2}{*}{ (PGI+PDO) \& Organic } & PGI+PDO & 27 & \multirow{2}{*}{$\begin{array}{c}\text { No } \\
(0.002)\end{array}$} & \multirow{2}{*}{$\begin{array}{c}\text { No } \\
(0.004)\end{array}$} \\
\hline & Organic & 12 & & \\
\hline
\end{tabular}


We obtained similar resuts for NPP as for PP. Figure 4 classifies each product combination product/level depending on PP and NPP. Organic producs had a higher NPP compared to PGI and PDO.

Finally, we offer a cross comparison of PP, NPP and costs. Crossing medians of each indicator (dotted line in figure 4 ) enables us to define 4 categories :

- $\quad$ The upper right quadrant corresponds to cases presenting a high level of PP and NPP. It includes almost all organic cases and a few PDO cases.

- The upper left quadrant, with 4 PDO cases and 2 PGI cases, includes cases with a high level of PP, but an intermediate or low level of NPP. These cases benefit from a high price premium, but face significantly higher costs compared to reference products.

- The lower right quadrant gathers together a few cases (3) with a low PP but average or high NPP. Costs for FQS are not much higher, and so a high PP is not required to compensate.

- Finally, the lower left quadrant represents the least profitable FQS cases (although in most cases they are still more profitable). The main PGI cases are in this quadrant, and half of the PDO cases.

Figure 4 confirms our results that most organic, PDO and PGI products benefit from positive PP and NPP. The cost differential between FQS and reference products may be expressed as the difference between PP and NPP, that is $P P-\mathrm{NPP}=\frac{\sum_{j}\left(\mathrm{c}_{j}^{*} P^{*}-\mathrm{c}_{j}^{r} P^{r}\right)}{P^{r}}$. The diagonal in figure 4 divided observations in two groups, revealing the cost differential: on the diagonal, costs have a similar weight in relation to FQS and the corresponding reference $\left(\sum_{j}\left(c_{j}^{*} P^{*}-c_{j}^{r} P^{r}\right)=0\right)$. For cases positioned to the right, costs are lower in relation to FQS. We noted that there are very few cases in this situation, as in most cases FQS have higher costs than reference products. This sitation only occurs for vegetal products, among them 2 organic cases emerged by having significantly lower cots than reference. 
Figure 4. Cross comparison analysis of Price Premium and Net Price Premium (median $\mathbf{P P}=0.61$ and median $\mathrm{NPP}=0.18$ )

Dotted lines indicate medians for PP and NPP

Diagonal line represents equality between PP and NPP

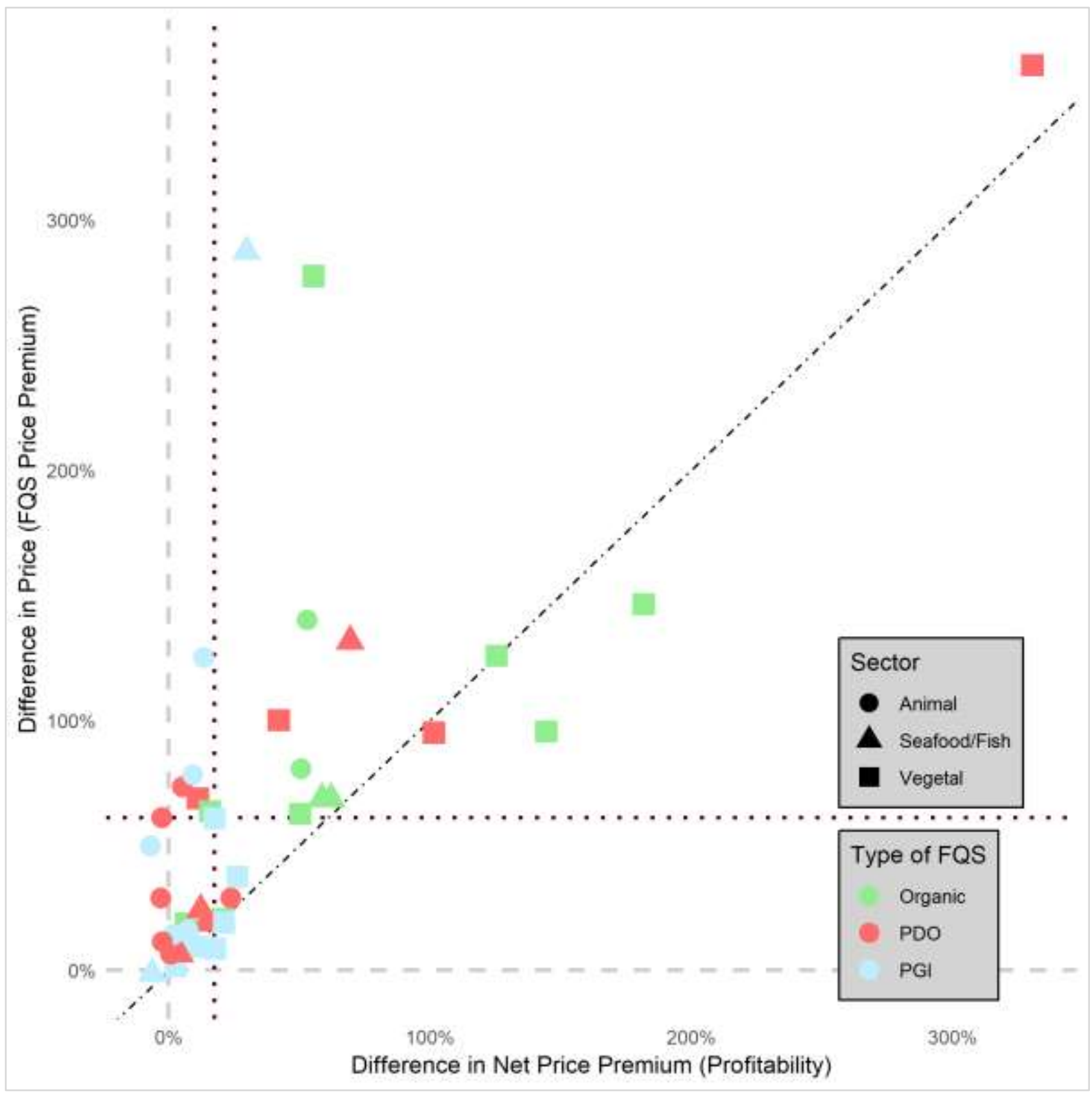

Using the Wilcoxon signed-rank test, we tested whether the median of the main production costs (expressed as share of turnover) are the same when considering FQS and reference products separately at upstream level and processing level, given that the cost structure differs between these levels (subsidies at upstream level). Due to the small sample size, these tests are not conducted by level $\mathrm{x}$ sector or level x FQS type. 
Table 5: Comparison of cost structures between FQS and reference products using Wilcoxon signed-rank tests

\begin{tabular}{|c|c|c|c|c|}
\hline $\begin{array}{l}\text { Same } \\
\text { median } \\
\text { for }\end{array}$ & $\begin{array}{c}\# \\
\text { observations }\end{array}$ & $\begin{array}{c}\text { DeltalC }= \\
I^{\mathrm{FQS}}-\mathrm{IC}^{\text {Ref }}=0\end{array}$ & $\begin{array}{l}\text { Delta Wages = } \\
\text { Wages }^{\text {FQS }}-\text { Wages } \\
\text { Ref }_{=} 0\end{array}$ & $\begin{array}{c}\text { Delta Sub }= \\
\text { Sub }^{\mathrm{FQS}}-\mathrm{Sub}^{\mathrm{Ref}}=0\end{array}$ \\
\hline $\begin{array}{l}\text { Upstream } \\
\text { level }\end{array}$ & 22 & $\begin{array}{c}\text { No } \\
\text { Prob }>|z|= \\
0.0003\end{array}$ & $\begin{array}{c}\text { Yes } \\
\text { Prob }>|z|=0.61\end{array}$ & $\begin{array}{c}\text { Yes } \\
\begin{array}{c}\text { Prob }>|z|=0.39 \\
(\#\end{array} \\
\text { observations=20) }\end{array}$ \\
\hline $\begin{array}{l}\text { Processing } \\
\text { level }\end{array}$ & 17 & $\begin{array}{c}\text { No } \\
\text { Prob }>|z|=0.12\end{array}$ & $\begin{array}{c}\text { Yes } \\
\text { Prob }>|z|=0.52\end{array}$ & \\
\hline
\end{tabular}

IC = Intermediate Consumption; Sub = Subsidies; FQS = FQS product; Ref = reference product.

In terms of cost structure, wages and subsidies have the same median for FQS products and reference products, however, this does not extend to intermediate consumption. The differential in quality rent derives from lower intermediate consumption for FQS products than for reference products.

Four out of 39 product*level pairs exhibit a negative quality rent (Gyulai sausage and Lofoten Stockfishÿ at farm level, Clotted cream and Parmigiano Reggiano at processing level). Regardless of the sector and the level of the value chain, organic products make it possible to obtain a quality rent.

\section{Discussion and conclusions}

This article addressed the issue of economic incentives to provide quality for credence goods supported by European food quality schemes. Farmers/fishers, processors and retailers use FQS products in a strategic way, as an effective means to obtain added value and for the purposes of risk management. They offer a range of differentiated products, and they leverage this diversity to increase their resilience (Vandecandelaere et al., 2018). Our results confirm price and profitability advantages offered by FQS. By means of an ambitious and collective research programme, we provide new insights on FQS impacts at different levels of the value chains, in relation to different sectors and FQS types. One of the main original aspects of this paper lies in a joint analysis of GI and organic value chains. Our analysis demonstrates a positive price premium and profitability for FQS products compared to reference ones. At upstream and processing levels, this result is in part due to lower intermediate consumption for FQS products with respect to reference product price.

An interesting result of our study is that net price premium (i.e. taking into account additional costs) is significantly higher for organic products than for PDO and PGI products. Types of quality schemes differ in terms of quality differentiation and ability to meet consumer expectations. This may influence the level of price premium which they generate. 
In relation to GI products, positive price premium and net price premium are consistent with the potential market power producers of GI products can exercise (Zago and Pick, 2004; Chambolle and Giraud-Héraud, 2005; Joslin, 2006; Mérel, 2009). Organic producers also benefit from market power at some stage, however the situation in relation to the organic label is quite different. Common European rules have regulated organic production and processing since 1991. This label benefits from wide recognition by consumers. Relying on the market basket analysis, Hassan et al. (2009) concluded that an "organic attitude" exists. The empirical literature addresses a major concern, namely, the motivations of buyers of organic products (see survey in Hughner et al., 2007). Considerations related to health (Mondelaers et al., 2009; Griffith and Nesheim, 2013; Kriwy and Mecking, 2011), product quality (Abrams et al., 2010) and environmental protection (Durham, 2007; and Monier-Dilhan and Bergès, 2016) constitute the three main reasons for buying organic products. However, there is no consensus on the ranking of these motivations. Driven by increasing consumer demand for healthier, safer, and more environmentally friendly food products, the production of organic goods provides a rent to the economic agents of the chain. Organic products thus generate a high quality rent. They take advantages of a market with an increasing gap between demand and supply.

This study also highlights a high dispersion of price premium and profitability among FQS products. Since GI encompasses heterogeneous quality signals, it impacts economic value chains economics in different ways. Quality assurance schemes with higher quality standards (such as PDO) receive higher premiums than less stringent ones (such as PGI) (Deselnicu et al., 2013). However, our results show that variations are also significant within each GI type, irrespective of whether it is PDO or PGI. This reflects the fact that, in practice, the GI legal framework provides general guidelines that actors may implement in very different ways. EU Regulation 510/2006 stipulates that each PDO must comply with a product specification, but its application through production and processing specifications is quite flexible. Indeed, PDO are very heterogeneous in terms of the content and the degree of precision of their mandatory specifications. The decision process for PDO creation or development gives a central role to professional organizations (Ansaloni and Fouilleux, 2008), and each product specification reflects a local balance of power and interests.

Beside lower intermediate consumption for FQS products than for reference products (at upstream and processing levels), each GI economic performance is related to many factors crossing different scales and determinants: cultural, historical, institutional, organisational, and natural factors; all linked to territorial specificities and national context (Barjolle and Sylvander, 2002). Some countries have a long tradition in GI, which may contribute to greater consumer recognition of GI and economic impact. Nevertheless, even when considering a single country, GI specific requirements and history may be very heterogeneous, reflecting divergence in consumers' WTP, value chain control by actors and costs structure, role and power of professional organizations (Ansaloni and Fouilleux, 2008; Areté, 2013; Cei et al., 2018). Some GI are well-established (high notoriety), linked to consumer recognition (in the local, national or international market; or a mixture of destinations - Parmigiano cheese for example). The success of a particular FQS is reflected in its seniority. Our study includes both longstanding FQS cases and very recent ones. This may affect the economic result, in relation to consumer and market recognition and 
reputation and the necessary time to establish mature and efficient collective organisation. Price premium level may also be connected to events across the whole sector, in particular the influence of private trademarks with high notoriety, or other kind of labels (McCluskey and Loureiro, 2003; Deselnicu et al., 2013).

Overall, organic products perform better than GIs. Nevertheless, organic FQS encompass a high level of variability in terms of price premium and net price premium. This confirms some of the insights made by Sanders et al. (2016). The level of premium and its distribution depends on the structure of the supply chain, the development of the sector and the lag between demand and supply. Our study does not include sufficient data to establish on a statistical basis further determinants in relation to each FQS type. However, the analysis of case study monographies from Strenght to Food H2020 project tends to confirm the impacts of context on the variation in magnitude of price premium and net price premium (stage of market development, national demand, organisation of actors, etc.).

Another factor that may explain this high variation in results is the difference in market sizes, and the effect this may have on the production scale of the FQS product compared to the reference product (De Roest and Menghi, 2000). A high level of premium and profitability may be explained because a FQS product has a very restricted niche market, dedicated to a specific consumer segment. Economic performance also depends on the market power of various actors. In a niche market, it is easier to achieve better results. However, this implies that such an option is viable only for few actors. This situation raises the question of how to use FQS as part of a policy toolbox to improve the economic sustainability of the European food sector. Indeed, if FQS is used as a general political strategy for the food sector, quality rent may decrease or disappear. A trade-off exists between volume and rent: increasing offer tends to reduce prices. This issue is particularly relevant to the organic sector, questioning its capacity to deal with upscaling and massive supply increase (Guthman, 2018; Crowder and Reganold, 2015), and it also arises for some succesfull GI products (De Roest and Menghi, 2000). Currently, although organic production is growing fast, prices remains high since organic demand is growing even faster. This trade-off may be resolved if diversity in supply is connected to consumers' willingness to pay for a large and specific basket of FQS. Moreover, strong collective organisation among value chain actors enables the development of strategies to preserve quality and control supply level and value distribution. This could be the case even in relation to a FQS product with high volume (like Comté or Parmiggiano). Finally, our results confirm that fostering quality as a pillar of european agricultural policy is a credible scenario to ensure sustainability of the farm and food sector (Afterres, 2050, 2014; Aubert et al., 2019).

This paper's contribution is its analysis of the potentially higher profitability of FQS products compared to reference products. The originality of this study stems from the fact that it is part of a comprehensive research framework, simultaneously covering the main sustainability issues (economic, social and environmental pillars) in relation to a diverse range of products (sectors, FQS types) in 14 countries and at different levels of the value chains. These issues merit further exploration in order to develop analysis of the economic sustainability of FQS. In addition to price premium and profitability, FQS can have an impact on other economic aspects, in particular when 
considering economic resilience in all its dimensions (see SAFA Indicators for example - FAO, 2013) and the externalities and public goods that FQS may generate. Effects on price volatility and transmission are important issues to establish a comprehensive overview of the economic sustainability of FQS (Ferrer-Perez et al., 2019). The externalities and public goods that FQS may generate (Vandecandelaere et al., 2018; Belletti et al., 2017; Regandol and Wachter, 2016) are also key issues to gain an understanding of their economic impact as a whole.

\section{Acknowledgements}

This project received funding from the European Union's Horizon 2020 research and innovation programme under grant agreement No. 678024. The authors would like to thank all the people and institutions who collected or provided raw data for this publication. Statistical analysis was conducted using the R and Stata softwares. 


\section{References}

Afterres 2050, “Quelle utilisation des terres en 2050 en France ?"[ France: SOLAGRO; (2014) p. 70. https://solagro.org/images/imagesCK/files/publications/f5_afterres2050-web.pdf

Agence Bio, “Chiffres clés de l'agriculture biologique en 2017”. (2018). http://www.agencebio.org/sites/default/files/upload/agencebiodossierdepressechiffres220218.pdf

Ahrendsen B. L. and E. Majewski. "Protected Geographical Indication Recognition and Willingness to Pay: a Case of Grojec Apple." Applied Studies in Agribusiness and Commerce, vol. 11. Number 3-4. (2017): 73-80.

Allaire, G., T. Poméon, E. Maigné, E. Cahuzac, M. Simioni, and Y. Desjeux. “Territorial analysis of the diffusion of organic farming in France: Between heterogeneity and spatial dependence." Ecological Indicators, 59 (Decembre 2015): 70-81. DOI : 10.1016/j.ecolind.2015.03.009

AND-International. "Value of production of agricultural products and foodstuffs, wines, aromatised wines and spirits protected by a geographical indication (GI)." Commissioned by the European Commission (tender no. AGRI-2011-EVAL-04). (2012). Available at ec.europa.eu/agriculture/external-studies/2012/value-gi/final-report_en.pdf.

Ansaloni M. and E. Fouilleux. "Terroir et Protection de l'Environnement : Un Mariage Indésirable ? A Propos d'Intégration de Critères Environnementaux dans un Instrument de Politique Agricole." Politiques et Management Public 26 no.4 (2008):3-24.

Areté. "Study on assessing the added value of PDO/PGI products." Executive summary. (2013): https://ec.europa.eu/agriculture/sites/agriculture/files/external-studies/2013/added-valuepdo-pgi/exec-sum_en.pdf

Aubert J.-M., M.-H. Schwoob and X. Poux. "Agroecology and carbon neutrality in Europe by 2050: what are the issues? Findings from the TYFA modelling exercise". IDDRI, (2019): Study $\mathrm{N}^{\circ} 02 / 19$.

Barjolle D. and P. Jeanneaux. "Raising rivals costs strategy and localised agro-food systems in Europe." International Journal Food System Dynamics 3, no.1 (2012): 11-21. doi: 10.18461/ijfsd.v3i1.312

Barjolle D., and B. Sylvander. "Some factors of success for origin labelled products in agri-food supply chains in Europe: market, internal resources and institutions." Economies et sociétés 25.9-10 (2002): 1441.

Bellassen V., G. Giraud, M. Hilal, F. Arfini, A. Barczak, A. Bodini, M. Brennan, M. Drut, M. Duboys de Labarre, M. Gorton, M. Hartmann, E. Majewski, P. Muller, S. Monier-Dilhan, T. Poméon, B. Tocco, A. Tregear, M. Veneziani, M.-H. Vergote, G. Vitterso, P. Wavresky, A. Wilkinson. "Methods and indicators for measuring the social, environmental and economic impacts of food quality schemes." Strength2Food project, deliverable 3.2. (2016): https://www.strength2food.eu/publications/

Bellassen V., F. Arfini, F. Antonioli, A. Bodini, M. Brennan, R. Courbou, L. Delesse, M. Donati, M. Drut, M. Duboys de Labarre, O. Dupont, J. Filipović, L. Gauvrit, G. Giraud, M. Gorton, M. Hilal, E. Husson, K. M. Laitala, E. Majewski, A. Malak-Rawlikowska, S. MonierDilhan, P. Muller, T. Poméon, B. Ristic, M. Sayed, B. Schaer, Z. Stojanovic, A. Paget, B. Tocco, 
E. Toque, A. Tregear, M. Veneziani, M-H. Vergote, G. Vitters $\varnothing$, A. Wilkinson. "Results and lessons from pilot studies and final set of verified indicators for impact measurement of FQS, PSFP and SFSC: Evidence from the Comté PDO cheese, Parmigiano Reggiano PDO cheese, Serbian organic raspberries, County Durham school meals, Locavorium shop and Korycin Cheese." Strength2Food project, deliverable 3.4. https://www.strength2food.eu/publications/

Belletti G., A. Marescotti, and J.M. Touzard. "Geographical indications, public goods, and sustainable development: The roles of actors' strategies and public policies." World Development 98 (2017): 45-57.

Bonanno A., C. Russo and L. Menapace. "Market power and bargaining in agrifood markets: A review of emerging topics and tools." Agribusiness. 34 (2018): 6-23. https://doi.org/10.1002/agr.21542

Bontemps C., Z. Bouamra-Mechemache Z. and M. Simioni. "Quality Labels and Firm Survival: Some First Empirical Evidence." European Review of Agricultural Economics, vol. 40, $\mathrm{n}^{\circ}$ 3, (2013): 413-439.

Caswell, J. A. and S. Anders. "Private vs. Third Party vs. Government Labeling. In The Handbook of the Economics of Food Consumption and Policy." Ed. Jayson Lusk, Jutta Rosen, and Jason Shogren, (2011): 472-498. Oxford, United Kingdom: Oxford University Press.

Cei L., E. Defrancesco, and G. Stefani. "From geographical indications to rural development: A review of the economic effects of European Union policy." Sustainability 10.10 (2018): 3745.

Chambolle, C. and E. Giraud-Héraud. "Certification of Origin as a Non-Tariff Barrier." Review of International Economics. 13 (2005): 461-471.

Crowder, W., and J. P. Reganold. "Financial competitiveness of organic agriculture on a global scale." Proceedings of the National Academy of Sciences 112.24 (2015): 7611-7616.

McCluskey J.A. 2000. "Game Theoretic Approach to Organic Foods: An Analysis of Asymmetric Information and Policy." Agricultural and Resource Economics Review. 29/1 (April) $1-9$.

McCluskey J.J. and M.L. Loureiro. 2003. "Consumer Preferences and Willingness to Pay for Food Labeling: A Discussion of Empirical Studies." Journal of Food Distribution Research. 34, no.3 (2003): 95-102.

Deselnicu O.C., M. Costanigro, D.M. Souza-Monteiro and D.T.McFadden.. "A MetaAnalysis of Geographical Indication Food Valuation Studies: What Drives the Premium for Origin-Based Labels?" Journal of Agricultural and Resource Economics. Vol. 38, No. 2 (August 2013): 204-219. https://www.jstor.org/stable/23496751

Dimitri, C., and R.L. Dettmann. 2012. "Organic Food Consumers. What Do We Really Know about Them?” British Food Journal. 114 no.8 (2012): 1157-1183.

European Commission. "Impact assessment on geographical indications. Accompanying document to the Proposal for a Regulation of the European Parliament and of the Council on agricultural product quality schemes." COM 733 final 2010/0353 (COD). Commission staff working paper, (2010) $83 \mathrm{pp}$.

FAO. Sustainability Assessment of Food and Agricultural System: Indicators. Roma, (2013) 271 pp. http://www.fao.org/fileadmin/templates/nr/sustainability_pathways/docs/ SAFA_Indicators_final_19122013.pdf 
Ferrer-Pérez H., F. Arfini, and J.M. Gil. "Modelling Price Transmission within the Supply Chain under a European Protected Designation of Origin Framework: The Case of Parmigiano Reggiano in Italy." Social Sciences. 8 no. 87 (2019).

Fotopoulos C. and A. Krystallis A. "Quality labels as a marketing advantage: The case of the "PDO Zagora" apples in the Greek market." European Journal of Marketing. Vol. 37 Issue: 10, (2003):1350-1374, https://doi.org/10.1108/03090560310487149

Garavaglia C. and P. Mariani P. "How Much Do Consumers Value Protected Designation of Origin Certifications? Estimates of willingness to Pay for PDO Dry-Cured Ham in Italy." Agribusiness. Volume33, Issue3, (Summer 2017): 403-423.

Guthman, Julie. "1 The (continuing) paradox of the organic label." Alternative Food Politics: From the Margins to the Mainstream (2018).

Hassan D., S. Monier-Dilhan, V. Nichèle and S. Simioni. 2009. "Organic Food Consumption Patterns." Journal of Agricultural and Food Industrial Organization 7no.2 (2009): 1-23. ISSN (Online) 1542-0485. DOI: 10.2202/1542-0485.1269.

ISMEA - Qualivita. "Rapporto ISMEA-Qualivita 2018 sulle produzioni agroalimentari e vitivinicole italiane DOP IGP STG”. (2019) https://www.qualivita.it/xvi-rapporto-ismeaqualivita-2018/\#!

Josling T. "The War on Terroir: Geographical Indications as a Transatlantic Trade Conflict." Journal of Agricultural Economics. 57 (2006):615-641.

London School of Economics. "Evaluation of the CAP Policy on Protected Designations of Origin (PDO) and Protected Geographical Indications (PGI)". Final Report; European Commission: Brussel, Belgium, (2008).

Maigné E., S. Monier-Dilhan and T. Poméon. "Consumer's environment and demand for organic food". Journal of Organics 4 no.1 (2017): 3-20.

Marette S. "Quality, market mechanisms and regulation in the food chain." Bio-based and Applied Economics; 5 no. 3(2016): 217-235. , DOI: 10.13128/BAE-18766

Mérel P.R. "Measuring Market Power in the French Comté Cheese Market." European Review of Agricultural Economics, vol. 36, (March 2009): 31-51. DOI: $10.1093 /$ erae/jbp004

Panin B., H. El Bilali and S. Berjan. "Factors influencing consumers' interest in protected designation of origin products in Serbia". Agriculture \&Forestry, Vol. 61, Issue 1 (2015): 91-97.

Parrott N., N. Wilson and J. Murdoch. 2002. "Spatializing Quality: Regional Protection and the Alternative Geography of Food." European Urban and Regional Studies, 9 no.3 (2014): 241-261. https://doi.org/10.1177/096977640200900304

Reganold, J. P., and J. M. Wachter. "Organic agriculture in the twenty-first century." Nature plants 2.2 (2016): 15221.

Roest K. de, and Al. Menghi. "Reconsidering 'traditional'food: the case of Parmigiano Reggiano cheese." Sociologia ruralis 40.4 (2000): 439-451.

Rudow K. "Less favoured area payments - impacts on the environment, a German perspective.” Agricultural Economics - Czech, 60 (2014): 260-272. 
Sanders J., D. Gambelli, J. Lernoud, S. Orsini, S. Padel, M. Stolze, H. Willer and R. Zanoli. "Distribution of the added value of the organic food chain." Braunschweig: Thünen Institute of Farm Economics. ( 2016).

Vandecandelaere E., Teyssier C., Barjolle D., Jeanneaux P., Fournier S., Beucherie O., 2018. Strengthening sustainable food systems through geographical indications, an analysis of economic impacts. FAO, Rome, 135p

Wier M., K. O’Doherty, L. Andersen, K. Millock, and L. Rosenkvist. "The Character of Demand in Mature Organic Food Markets: Great Britain and Denmark Compared." Food Policy 33 no.5 (2008): 406-421.

Zago, A.M., and D. Pick. "Labeling Policies in Food Markets: Private Incentives, Public Intervention, and Welfare Effects." Journal of Agricultural and Resource Economics 29 (2004):150-165. 


\section{Appendix 1}

Table A 1. List of available products

\begin{tabular}{|c|c|c|c|c|c|}
\hline Case studied & $\begin{array}{l}\text { Kind of } \\
\text { product }\end{array}$ & FQS & $\begin{array}{l}\text { Upstrea } \\
\mathrm{m}\end{array}$ & Processing & Downstream \\
\hline $\begin{array}{l}\text { Buon Ma Thuot } \\
\text { coffee }\end{array}$ & Vegetal & PGI & Yes & Yes & Yes \\
\hline Doi Chaang coffee & Vegetal & PGI & Yes & Yes & Yes \\
\hline Gyulai sausage & Animal & PGI & No & Yes & Yes \\
\hline Kastoria apple & Vegetal & PGI & Yes & Yes & No \\
\hline $\begin{array}{l}\text { Kaszubska } \\
\text { Strawberry }\end{array}$ & Vegetal & PGI & Yes & No & No \\
\hline Lofoten Stockfishÿ & Seafood & PGI & Yes & Yes & Yes \\
\hline $\begin{array}{l}\text { Sobrasada Porc } \\
\text { Negre }\end{array}$ & Animal & PGI & Yes & Yes & No \\
\hline Ternasco de Aragon & Animal & PGI & Yes & Yes & Yes \\
\hline $\begin{array}{l}\text { Thung Kula Rong- } \\
\text { Hai H }\end{array}$ & Vegetal & PGI & Yes & Yes & Yes \\
\hline $\begin{array}{l}\text { Cornish cotted } \\
\text { cream }\end{array}$ & Animal & PDO & Yes & Yes & Yes \\
\hline Comte cheese & Animal & PDO & Yes & Yes & Yes \\
\hline Dalmatian prusut & Animal & PDO & Yes & Yes & No \\
\hline Kalocsai paprika & Vegetal & PDO & Yes & Yes & Yes \\
\hline $\begin{array}{l}\text { Opperdoezer Ronde } \\
\text { potato }\end{array}$ & Vegetal & PDO & Yes & No & No \\
\hline PDO olive oil & Vegetal & PDO & No & Yes & Yes \\
\hline $\begin{array}{l}\text { Parmigiano } \\
\text { Reggiano }\end{array}$ & Animal & PDO & Yes & Yes & Yes \\
\hline $\begin{array}{l}\text { Phu Quoc Fish } \\
\text { Sauce }\end{array}$ & Seafood & PDO & Yes & Yes & Yes \\
\hline $\begin{array}{l}\text { Saint-Michel bay } \\
\text { mussels }\end{array}$ & Seafood & PDO & Yes & No & Yes \\
\hline Zagora apple & Vegetal & PDO & Yes & Yes & No \\
\hline Organic flour & Vegetal & Organic & Yes & Yes & Yes \\
\hline Organic pasta & Vegetal & Organic & Yes & Yes & Yes \\
\hline Organic pork & Animal & Organic & Yes & No & Yes \\
\hline Organic raspberries & Vegetal & Organic & Yes & Yes & Yes \\
\hline Organic rice & Vegetal & Organic & Yes & Yes & Yes \\
\hline Organic salmon & Seafood & Organic & Yes & Yes & Yes \\
\hline Organic tomatoes & Vegetal & Organic & Yes & Yes & Yes \\
\hline Organic yoghurt & Animal & Organic & Yes & Yes & Yes \\
\hline Total & \multicolumn{2}{|c|}{69} & 25 & 23 & 21 \\
\hline
\end{tabular}




\section{Appendix 2}

Table A 2. Data sources and reference product

\begin{tabular}{|c|c|}
\hline Case studied & Reference product \\
\hline $\begin{array}{l}\text { Buon Ma Thuot } \\
\text { coffee }\end{array}$ & Non-PGI coffee from Dak Lak province in Vietnam \\
\hline Doi Chaang coffee & Non-PGI coffee from the same province \\
\hline Gyulai sausage & Non-PGI Hungarian sausage \\
\hline Kastoria apple & Kissavos apples (non-GI apples from another region) \\
\hline $\begin{array}{l}\text { Kaszubska } \\
\text { Strawberry }\end{array}$ & National average in Poland \\
\hline Lofoten Stockfishÿ & Clipfish (cod) in Norway \\
\hline $\begin{array}{l}\text { Sobrasada Porc } \\
\text { Negre }\end{array}$ & Non-PDO sobrasada in the region (Islas Baleares) \\
\hline Ternasco de Aragon & Non-PGI lamb in the same region (Aragon) \\
\hline $\begin{array}{l}\text { Thung Kula Rong- } \\
\text { Hai H }\end{array}$ & $\begin{array}{l}\begin{array}{l}\text { Non certified rice from the same region (90\% of GI rice is organic as } \\
\text { well) }\end{array}\end{array}$ \\
\hline $\begin{array}{l}\text { Cornish cotted } \\
\text { cream }\end{array}$ & Conventional cream in Great Britain \\
\hline Comte cheese & PGI Emmental cheese produced in Central eastern French area \\
\hline Dalmatian prusut & Local non-PGI firm \\
\hline Kalocsai paprika & Imported Chinese pepper milled in Hungary \\
\hline PDO olive oil & National average in Croatia \\
\hline $\begin{array}{l}\text { Opperdoezer Ronde } \\
\text { potato }\end{array}$ & Regular potato in neighbouring IJsselmeerpolders region \\
\hline $\begin{array}{l}\text { Parmigiano } \\
\text { Reggiano }\end{array}$ & Biraghi cheese (similar non-PDO cheese) \\
\hline $\begin{array}{l}\text { Phu Quoc Fish } \\
\text { Sauce }\end{array}$ & Non-PDO fish sauce from same region \\
\hline $\begin{array}{l}\text { Saint-Michel bay } \\
\text { mussels }\end{array}$ & National average for TSG Bouchot mussels \\
\hline Zagora apple & Kissavos apples (non-GI apples from another region) \\
\hline Organic flour & National average in France \\
\hline Organic pasta & $\begin{array}{l}\text { Simulated conventional farms with sample characteristics and } \\
\text { conventionnal pasta facotry in Poland }\end{array}$ \\
\hline Organic pork & National average in Germany \\
\hline Organic raspberries & Conventional raspberries in Serbia \\
\hline Organic rice & Non-organic rice in France (mostly PGI) \\
\hline Organic salmon & Conventional salmon in Norway \\
\hline Organic tomatoes & $\begin{array}{l}\text { Conventional processed tomatoes in the same region (Emilia- } \\
\text { Romagna) }\end{array}$ \\
\hline Organic yoghurt & National average in Germany \\
\hline
\end{tabular}

